\title{
EFEKTIFITAS PELATIHAN MENGGUNAKAN MEDIA BOOKLET TERHADAP PENINGKATAN SIKAP DAN TINDAKAN IBU TENTANG DETEKSI DINI KARIES GIGI PADA SISWA SEKOLAH DASAR DI WILAYAH KERJA PUSKESMAS TELING ATAS KOTA MANADO
}

\author{
Jeineke E. Ratuela \\ Jurusan Keperawatan Gigi Poltekkes Kemenkes Manado \\ Email : jeinekeellenratuela@gmail.com
}

\begin{abstract}
ABSTRAK
Latar Belakang : Peran ibu sangat menentukan perilaku anak, sehingga ibu membutuhkan informasi dan panduan untuk mendorong kebiasaan anak dalam menjaga kebersihan gigi dan mulutnya sedini mungkin. Pendidikan kesehatan gigi melalui pelatihan merupakan salah satu intervensi untuk merubah perilaku ibu dari tidak tau menjadi tau dan dari tidak sehat menjadi sehat guna mencapai derajad kesehatan gigi anak setinggi-tingginya. Tujuan : Untuk mengetahui efektifitas pelatihan menggunakan media booklet terhadap peningkatan sikap dan tindakan ibu tentang deteksi dini karies gigi pada siswa Sekolah Dasar di wilayah kerja Puskesmas Teling Atas Kota Manado. Metode : metode analitik true experiment (eksperimen sungguhan) dengan rancangan "One Group Pretest-Posttest". Teknik pengambilan sampel yaitu Accidental sampling berjumlah 78 orang siswa sekolah dasar di wilayah kerja puskesmas Teling Kota Manado. Pengumpulan data menggunakan kuesioner. Analisa data menggunakan uji paired samples $T$ Test. Hasil : Sikap responden sebelum diberikan pelatihan terbanyak pada kategori cukup yaitu sebanyak 51 responden $(65 \%)$ dan sesudah pelatihan menjadi baik sebanyak 69 responden (88\%). Berdasarkan analisis data diperoleh sikap responden (pre test $=15.93$, post test $=22.30$ ) terjadi peningkatan sikap ibu sebesar 6.37 point, dengan nilai $(p=0,000<0,05)$. Hal ini menunjukkan bahwa ada peningkatan sikap responden sebelum dan sesudah diberikan pelatihan. Tindakan responden sebelum diberikan pelatihan terbanyak pada kategori cukup yaitu sebanyak 51 responden $(65 \%)$ dan sesudah pelatihan tindakan responden meningkat menjadi baik sebanyak 69 responden $(88 \%)$. analisis data tindakan responden diperoleh (pre test $=3.28$, post test $=5.87$ ) terjadi peningkatan tindakan ibu sebesar 2.58 point dengan nilai $(\mathrm{p}=0,000<0,05)$. Hal ini menunjukkan bahwa ada peningkatan tindakan responden sebelum dan sesudah diberikan pelatihan. Kesimpulan : terdapat perbedaan sikap dan tindakan ibu sebelum dan sesudah pelatihan deteksi dini menggunakan media booklet yang berarti bahwa pelatihan tentang deteksi dini karies gigi menggunakan booklet sangat efektif dalam meningkatkan sikap dan tindakan ibu pada siswa SD di wilayah kerja Puskesmas Teling Atas Kota Manado.
\end{abstract}

\section{Kata Kunci: Pelatihan, Media Booklet, Sikap, Tindakan Ibu, Deteksi Dini Karies}

Background: The role of the mother greatly determines the behavior of the child, so the mother needs information and guidance to encourage children's habits in maintaining the cleanliness of their teeth and mouth as early as possible. Dental health education through training is one of the interventions to change the behavior of mothers from not knowing to know and from being unhealthy to being healthy in order to achieve the highest degree of dental health of children. Objective: To determine the effectiveness of the training using booklet media on improving maternal attitudes and actions regarding early detection of dental caries in elementary school students in the working area of Teling Public Health Center in Manado City. Method: this study was true experiment analytical method with the design of "One Group Pretest-Posttest". The sampling technique is accidental sampling totaling 78 elementary school students in the working area of Teling City Manado health center. Data collection using a questionnaire. Data analysis 
using paired samples $\mathrm{T}$ Test. Results: The attitude of the respondents before being given the most training in the sufficient category was as many as 51 respondents $(65 \%)$ and after the training became good as many as 69 respondents $(88 \%)$. Based on the data analysis, the attitudes of respondents (pre test $=15.93$, post test $=22.30$ ) were obtained by an increase in maternal attitudes of 6.37 points, with a value $(\mathrm{p}=0,000<0,05)$. This shows that there was an increase in the attitude of respondents before and after training. The respondent's actions before being given the most training in enough categories were 51 respondents $(65 \%)$ and after training the respondent's actions improved to 69 respondents $(88 \%)$. data analysis of respondent's actions was obtained (pre test $=3.28$, post test $=5.87$ ) there was an increase in maternal action by 2.58 points with a value $(\mathrm{p}=0,000<0,05)$. This shows that there was an increase in respondent's actions before and after training. Conclusion: there are differences in attitudes and actions of mothers before and after early detection training using booklet media which means that training on early detection of dental caries using booklets is very effective in improving maternal attitudes and actions for elementary students in the Teling Upper Manado City Health Center working area.

\section{Keywords: Training, Media Booklet, Attitude, Mother's Action, Caries Early Detection}

\section{PENDAHULUAN}

Upaya kesehatan gigi perlu ditinjau dari aspek lingkungan, pendidikan, kesadaran masyarakat dan penanganan kesehatan gigi termasuk pencegahan dan perawatan. Aspek tersebut saling berhubungan dan saling mempengaruhi, baik cara pencegahan dan perawatan gigi masyarakat (upaya kesehatan gigi masyarakat) maupun keadaan kesehatan gigi masyarakat. Untuk mendapatkan hasil sebaik-baiknya dalam upaya kesehatan gigi (pencegahan penyakit gigi), perlu diketahui masalah yang berkaitan dengan proses terjadinya kerusakan gigi (karies) termasuk etiologi karies gigi, resiko yang menyebabkan timbulnya karies gigi dan juga faktor distribusi penduduk, lingkungan serta perilaku masyarakat terhadap kesehatan gigi. ${ }^{10}$

Berdasarkan Riset Kesehatan Dasar (Riskesdas) tahun 2013 menunjukkan bahwa penduduk yang berperilaku benar dalam merawat gigi yaitu $76,6 \%$, sedangkan penduduk yang bermasalah dengan kesehatan gigi sebanyak 25,9\%, namun penduduk yang mempunyai kesadaran untuk merawat gigi hanya $31,1 \%$ dan penderita yang tidak mau merawat giginya sebanyak $68,9 \% .^{4}$

Karies gigi jika tidak diketahui sejak dini dan dibiarkan berlanjut dapat menjadi parah, sehingga anak-anak perlu mendapat perhatian khusus dari orang tua, terutama umur 6 sampai 9 tahun dimana umur 6 tahun gigi molar permanen sudah mulai tumbuh sehingga lebih rentan dan terlebih dahulu terkena karies. Umur 9 tahun merupakan periode gigi bercampur dimana jumlah gigi permanen dan gigi sulung dalam rongga mulut hampir sama yaitu 14 gigi permanen dan 10 gigi sulung. Karies gigi adalah suatu penyakit jaringan gigi yang ditandai dengan kerusakan jaringan, dimulai dari permukan gigi (pit, fissure dan daerah interproximal) dan meluas kearah pulpa. Karies gigi merupakan penyakit gigi yang paling banyak ditemukan, meliputi semua usia dan lapisan masyarakat. $^{10}$

Kesehatan gigi dan mulut merupakan bagian dari kesehatan tubuh yang tidak dapat dipisahkan satu sama lain sebab kesehatan gigi dan mulut akan mempengaruhi kesehatan tubuh secara keseluruhan. Gigi merupakan salah satu bagian tubuh yang berfungsi untuk mengunyah, berbicara dan 
mempertahankan bentuk wajah. Mengingat kegunaannya sangat penting maka perlu untuk menjaga dan memelihara sedini mungkin agar dapat bertahan lama dalam rongga mulut. Penyebab timbulnya penyakit gigi dan mulut pada masyarakat salah satunya yaitu faktor perilaku dan sikap mengabaikan kebersihan gigi dan mulut. Hal tersebut dilandasi oleh kurangnya pengetahuan masyarakat akan pentingnya pemeliharaan gigi dan mulut. Pemeliharaan kesehatan gigi anak masih sangat tergantung pada orang dewasa terutama ibu. ${ }^{2}$

Peningkatan perilaku ibu sangat diperlukan untuk membantu anak dalam menemukan masalah-masalah kesehatan gigi dan mulut. Kesehatan gigi dan mulut anak tidak hanya tergantung pada anak namun peran orang tua dalam hal ini ibu turut menentukan baik tidaknya kesehatan gigi dan mulut seorang anak. ${ }^{2}$

Pendidikan kesehatan gigi melalui pelatihan merupakan salah satu intervensi untuk merubah perilaku ibu dari tidak tau menjadi tau dan dari tidak sehat menjadi sehat guna mencapai derajad kesehatan gigi anak setinggi-tingginya. ${ }^{2}$ Pelatihan kesehatan gigi dan mulut dapat dilakukan melaui upaya promotif dan preventif biasanya membutuhkan alat bantu (media) untuk memudahkan sasaran menerima pesan yang disampaikan. Menurut Dale, penangkapan pengetahuan yang diberikan melalui indera penglihatan ialah $75 \%$ sampai $87 \%$, melalui indera pendengaran $13 \%$ dan indera lainnya $12 \%$. Semakin banyak indera yang dilibatkan dalam penagkapan pesan maka semakin mudah pesan dapat diterima oleh sasaran. ${ }^{6}$ Hasil penelitian Malikatul. ${ }^{5}$ tentang media booklet dalam pemberian penyuluhan menunjukkan bahwa media booklet memberikan pengaruh yang positif dalam meningkatkan pengetahuan ibu menyusui.
Berdasarkan survei awal yang dilakukan pada 32 siswa di kelas II dan III SD Kartika XXIII Teling diperoleh sebanyak 28 siswa memiliki gigi berlubang lebih dari 2 gigi. Informasi dari Puskesmas Teling bahwa beberapa Sekolah Dasar di Wilayah Puskesmas Teling Atas Kota Manado sudah pernah diikutkan dalam program pelatihan kader UKGS meliputi guru dan dokter gigi kecil namun orang tua dalam hal ini ibu belum pernah diikutsertakan dalam dalam kegiatan pelatihan.

Penelitian ini bertujuan untuk mengetahui efektifitas pelatihan deteksi dini karies gigi menggunakan booklet terhadap peningkatkan perilaku (pengetahuan, sikap dan tindakan) ibu pada siswa sekolah dasar di wilayah kerja Puskesmas Teling Atas Kota Manado.

\section{METODOLOGI}

Metode penelitian yang digunakan yaitu metode analitik true experiment (eksperimen sungguhan) dengan rancangan "One Group Pretest-Posttest” yang memungkinkan peneliti dapat menguji perubahan-perubahan yang terjadi setelah adanya eksperimen. ${ }^{8}$ Penelitian dilakukan pada bulan JuniSeptember 2017 di Sekolah Dasar Kartika XXI-1 Manado wilayah kerja Puskesmas Teling Atas Kota Manado.

Variabel bebas pada penelitian ini yaitu pelatihan menggunakan booklet dan variabel terikat yaitu : peningkatan sikap dan tindakan ibu tentang deteksi dini karies gigi pada siswa sekolah dasar di wilayah kerja Puskesmas Teling Atas Kota Manado. Instrumen dalam penelitian ini booklet dan kuesioner.

Populasi dalam penelitian ini yaitu seluruh orang tua siswa sekolah dasar kelas II dan III SD Kartika XXI-1 wilayah kerja 
Puskesmas Teling Atas Kota Manado. Berjumlah 78 orang tua siswa.

\section{HASIL}

1. Distribusi karakteristik responden penelitian dapat dilihat pada tabel 1

Tabel 1. Karakteristik Responden

\begin{tabular}{lccc}
\hline \multicolumn{2}{c}{$\begin{array}{c}\text { Karaktersistik } \\
\text { Responden }\end{array}$} & Frekuensi & $\%$ \\
\cline { 1 - 3 } Tingkat & SMP & 5 & 6.0 \\
Pendidikan & SMA & 43 & 55.0 \\
Ibu & PT & 30 & 38.0 \\
& Total & 78 & 100.0 \\
\hline Pekerjaan & PNS & 37 & 47.0 \\
Ibu & SWASTA & 27 & 35.0 \\
& IRT & 14 & 18.0 \\
& Total & 78 & 100.0 \\
\hline
\end{tabular}

menunjukkan bahwa tingkat pendidikan responden terbanyak tamatan Sekolah Lanjutan Tingkat Atas (SLTA) yaitu 43 responden $(55 \%)$ dan paling sedikit tamatan Sekolah Menengah Pertama (SMP) yaitu 5 responden (6\%). Distribusi karakteristik responden berdasarkan jenis pekerjaan menunjukkan bahwa jenis pekerjaan responden terbanyak Pegawai Negeri Sipil (PNS) yaitu 37 responden (47\%) dan paling sedikit Ibu Rumah Tangga (IRT) yaitu 14 responden (18\%).

2. Distribusi Sikap dan Tindakan responden sebelum (Pre Test) dan sesudah (Post Test) pelatihan tentang deteksi dini karies gigi pada siswa sekolah dasar di wilayah kerja Puskesmas Teling Atas Manado.

$\begin{array}{ccc}\text { Distribusi } & \text { karakteristik } & \begin{array}{r}\text { responden } \\ \text { bendidikan }\end{array}\end{array}$

Tabel 2. Distribusi Sikap dan Tindakan Responden Sebelum (Pre Test) Dan

Sesudah (Post Test) Pelatihan Tentang Deteksi Dini Karies Gigi Pada Siswa

Sekolah Dasar Di Wilayah Kerja Puskesmas Teling Atas Manado

\begin{tabular}{clcc}
\hline \multirow{2}{*}{ NO } & \multicolumn{1}{c}{ VARIABEL } & PRE TES & POST TES \\
\hline 1 & & Sikap & \\
& a. Baik & $10(13 \%)$ & $69(88 \%)$ \\
& b. Cukup Baik & $51(65 \%)$ & $9(42 \%)$ \\
& c. Kurang Baik & $17(22 \%)$ & $0(0 \%)$ \\
\hline & Jumlah & $\mathbf{7 8}$ & $\mathbf{7 8}$ \\
Tindakan & & \\
& a. Baik & $22(28 \%)$ & $78(100 \%)$ \\
& b. Cukup Baik & $0(0 \%)$ & $0(0 \%)$ \\
& c. Kurang Baik & $56(72 \%)$ & $0(0 \%)$ \\
& Jumlah & $\mathbf{7 8}$ & $\mathbf{7 8}$ \\
\hline
\end{tabular}

Berdasarkan tabel 2 dapat dilihat bahwa sebelum pelatihan (Pre Test) sikap responden berada pada kriteria cukup baik yaitu sebanyak 51 responden $(65 \%)$, dan setelah pelatihan (Post Test) sikap responden menjadi baik sebanyak 69 responden $(88 \%)$, sedangkan tindakan responden sebelum pelatihan (Pre Test) berada pada kriteria 
kurang baik yaitu sebanyak 56 responden (72\%), dan setelah pelatihan (Post Test) tindakan responden menjadi baik sebanyak 78 responden (100).

3. Hasil analisis pengetahuan responden responden sebelum (Pre Test) dan sesudah
(Post Test) pelatihan tentang deteksi dini karies gigi pada siswa sekolah dasar di wilayah kerja Puskesmas Teling Atas Manado menggunakan uji statistic Paired Sample T-Test sebagai berikut :

Tabel 3. Analisis Uji T Berpasangan (Paired Sample T-Test) Peningkatan Sikap Responden Tentang Deteksi Dini Karies Gigi Pada Siswa Sekolah Dasar Di Wilayah Kerja Puskesmas Teling Atas Manado

\begin{tabular}{clllllll}
\hline \multicolumn{2}{c}{ Sikap } & & & & & \\
\cline { 1 - 2 } Sebelum & Sesudah & & Mean & $\mathrm{t}_{\text {hitung }}$ & Df & $A$ & $P$ \\
\hline 15.93 & 22.308 & 6.371 & 22.53 & 77 & 0.05 & 0.000 \\
\hline
\end{tabular}

Berdasarkan hasil analisis dengan uji paired sample T-Test sikap responden sebelum (Pre Test) pelatihan tentang deteksi dini karies gigi pada siswa sekolah dasar di wilayah kerja Puskesmas Teling Atas Manado menunjukkan bahwa nilai $t_{\text {hitung }}$ sebelum dan sesudah pelatihan mean $=$ 6.371dengan $t_{\text {hitung }}=22.53>\mathrm{t}_{\text {tabel }}=1.658$ pada df $77=1.658$ dan nilai $p=.000<0.05$. Hal ini menunjukkan bahwa terjadi peningkatan sikap responden sebelum dan sesudah diberikan pelatihan. Tindakan responden sebelum (Pre Test) pelatihan tentang deteksi dini karies gigi pada siswa sekolah dasar di wilayah kerja Puskesmas Teling Atas Manado menunjukkan bahwa nilai $t_{\text {hitung }}$ sebelum dan sesudah pelatihan mean $=2.589$ dengan $t_{\text {hitung }}=37.352>\mathrm{t}_{\text {tabel }}=$ 1.658 pada df $77=1.658$ dan nilai $p=.000<$ $0.05 \mathrm{Hal}$ ini menunjukkan bahwa terjadi peningkatan tindakan responden sebelum dan sesudah diberikan pelatihan

\section{PEMBAHASAN}

Salah satu strategi untuk memperoleh perubahan perilaku menurut WHO yang dikutip oleh Notoadmojo ${ }^{7}$ adalah dengan pemberian informasi untuk meningkatkan pengetahuan sehingga menimbulkan kesadaran dan dapat dilakukan dengan pemberian pelatihan. Dimana pengetahuan adalah hasil tahu dari manusia yang terdiri dari sejumlah faktor dan teori yang memungkinkan seseorang untuk dapat memecahkan masalah yang dihadapinya. Pengetahuan diperoleh baik dari pengalaman langsung maupun dari pengalaman orang lain.

Hasil analisa data Berdasarkan analisis data diperoleh sikap responden (pre test $=$ 15.93, post test $=22.30$ ) terjadi peningkatan sikap ibu sebesar 6.37 point, dengan nilai $(p=0,000<0,05)$. Hal ini menunjukkan bahwa ada peningkatan sikap responden sebelum dan sesudah diberikan pelatihan. Pelatihan tentang deteksi dini karies gigi disertai pemberian media booklet berisi informasi penting mengenai bagaimana mendeteksi karies gigi pada anak dimana penejelasannya disertai gambar yang menarik sehingga informasi dapat ditangkap dengan mudah. Melalui pembagian media booklet, responden lebih antusias mendengarkan sambil memberikan respons yang baik. Media booklet yang dibagikan kepada responden untuk dibawa pulang memungkinkan responden untuk mengingat 
kembali materi yang sudah diberikan karena jika lupa responden bisa membuka kembali materi tersebut.

Sikap merupakan reaksi atau respon seseorang tertutup terhadap suatu obyek. Ini berarti sikap harus sejalan dengan pengetahuan sehingga baik atau tidak status kesehatan gigi dan mulut seseorang dapat dipengaruhi oleh sikap sesorang (Fitri, 2011).

Hal ini dapat dilihat dari evaluasi yang dilakukan ternyata hasilnya sangat berpengaruh terhadap jawaban responden. Jadi, pelatihan yang disertai pemberian media booklet sangat efektif sehingga dapat mempengaruhi sikap seseorang.

Tabel 4. Analisis Uji T Berpasangan (Paired Sample T-Test) Peningkatan Tindakan Responden Tentang Deteksi Dini Karies Gigi Pada Siswa Sekolah Dasar Di Wilayah Kerja Puskesmas Teling Atas Manado

\begin{tabular}{cccccccc}
\hline \multicolumn{2}{c}{ Tindakan } & & & & & \\
\cline { 1 - 2 } Sebelum & Sesudah & & Mean & $\mathrm{t}_{\text {hitung }}$ & Df & $a$ & $P$ \\
\hline 3.28 & 5.87 & & 2.589 & 37.352 & 77 & 0.05 & 0.000 \\
\hline
\end{tabular}

Hasil analisa data mengenai perbedaan tindakan sebelum dan sesudah pelatihan deteksi dini menggunakan booklet diperoleh nilai 3.28 dan sesudah diberi pelatihan sebesar 5.87 , terjadi peningkatan nilai sebesar 2.59 point. Hal ini menunjukkan bahwa terjadi peningkatan tindakan responden setelah mendapat pelatihan. Pelatihan disertai praktek tentang bagaimana melakukan deteksi dini karies pada anak ternyata sangat bermanfaat karena responden bisa langsung mempraktekkan dengan melihat secara langsung keadaan gigi anak sehingga mempengaruhi sikap ibu. Media booklet yang dibagikan kepada responden untuk dibawa pulang memungkinkan responden untuk mengingat kembali materi yang sudah diberikan karena jika lupa responden bisa membuka kembali materi tersebut untuk mengidentifikasi karies gigi pada anak. Hal ini terbukti bahwa terdapat 15 anak yang sudah dilakukan penambalan di klinik Jurusan Keperawatan Gigi yang diantar langsung oleh ibu. Pengetahuan dan sikap ibu meningkat diikuti oleh tindakan ibu dengan langsung membawa anak untuk mendapat perawatan.
Berdasarkan penelitian Sumerti ${ }^{9}$ tentang faktor-faktor yang berhubungan dengan perilaku ibu dalam deteksi dini karies gigi anak balita ditemukan sikap ketidak pedulian ibu ketika menemukan tanda-tanda gigi berlubang pada anaknya sebanyak 80,3 $\%$. Sedangkan tindakan ibu yang tidak memeriksakan gigi ke sarana pelayanan kesehatan gigi sebanyak 71,7\%.

Hasil penelitian ini sejalan dengan penelitian Arini, N.P.D.T, 2016, yang menyatakan bahwa media booklet sangat efektif digunakan dalam pelatihan untuk meningkatkan pengetahuan dan keterampilan kader posyandu tentang kesehatan gigi dan mulut.

\section{KESIMPULAN}

Berdasarkan hasil penelitian diperoleh kesimpulan bahwa terdapat perbedaan pengetahuan sebelum dan sesudah pelatihan deteksi dini menggunakan media booklet yang berarti bahwa pelatihan tentang deteksi dini karies gigi menggunakan booklet sangat efektif dalam meningkatkan pengetahuan 
ibu pada siswa SD di wilayah kerja Puskesmas Teling Atas Kota Manado

\section{SARAN}

Setelah melaksanakan dan membahas hasil penelitian ini, maka penulis dapat memberikan saran yaitu :

1. Bagi Pihak Sekolah

a. Melakukan kerjasama lintas sektor dengan Puskesmas di Wilayah Kecamatan Teling Kota Manado, dalam upaya meningkatkan derajat kesehatan anak didik.

b. Dianjurkan, sebaiknya di kantin sekolah tidak menjual makanan yang manis dan mudah melekat dan menggantikannya dengan menjual buah-buahan yang berserat.

2. Bagi ibu-ibu agar

a. Memperhatikan kesehatan gigi anak dalam hal ini pertumbuhan gigi tetap yang mulai tumbuh pada usia 6 tahun

b. Mengingatkan anak untuk menjaga kesehatan gigi dengan menyikat gigi yang baik setiap hari sesudah makan dan memperhatikan makanan yang dikonsumsi anak baik di rumah maupun disekolah

3. Jika menemukan tanda-tanda karies gigi segera ke poliklinik gigi untuk mendapatkan perawatan lebih lanjut.

\section{DAFTAR PUSTAKA}

1. Agustin, M, 2014, Efektifitas Pendidikan Kesehatan Media Booklet Dibandingkan Audio Visual Terhadap Pengetahuan Orang Tua Tentnag Karies Gigi Pada Anak Usia 59 Tahun di Desa Makamhaji, Tesis,
Universitas Muhamadiyah Surakarta, (http://eprints.ums.ac.id/32230/1/03.pdf Diakses 10 Januari 2017

2. Budiharto, 2010, Ilmu Perilaku Kesehatan dan Pendidikan Kesehatan Gigi, EGC, Jakarta

3. Kemp J, Walters, C. Gigi si Kecil Cara Menjaga Kesehatan Gigi dan Gusi Anak. Erlangga. Jakarta

4. Kementerian Kesehatan RI., 2013. Riset Kesehatan Dasar, Badan Penelitian \& Pengembangan Tenaga Kesehatan Kemenkes. Laksana, Jakarta

5. Malikatul, M. Pengaruh Pendidikan Kesehatan Dengan Booklet Terhadap Peningkatan Nutrisi Ibu Laktasi.Tesis. Universitas Muhamadiyah Surakarta. (http://lib.ums.ac/125716-PER-216.pdf. Diakses 10 Januari 2017.

6. Machfoedz, I dan Suryani E, 2005, Pendidikan Kesehatan Bagiandari Promosi Kesehatan, Yogyakarta : Fitramaya

7. Notoatmojo, 2010, Promosi Kesehatan dan Ilmu Perilaku, Rineka Cipta, Jakarta

8. Swarjana, I.K. (2012). Metodologi Penelitian Kesehatan Tuntunan Praktis Pembuatan Proposal Penelitian.ANDI.Yogyakarta.

9. Sumerti, 2011, Faktor-faktor yang berhubungan dengan perilaku ibu dalam deteksi dini karies gigi pada balita di Kecamatan Kuta Utara Kabupaten Badung, Jurnal Kesehatan Gigi Vol.1No.1, Denpasar-Bali

10. Tarigan S, 2002, Karies Gigi, Hipocrates, Jakarta 